\title{
Subjective sleep quality and objective sleep physiology in migraineurs: a meta-analysis
}

E.C. Stanyer, MPsych, H. Creeney, MSc, A.D. Nesbitt, BM BCh, PhD, P. R. Holland,

PhD, J. Hoffmann, MD, PhD*.

From the Headache Group, Wolfson Centre for Age Related Diseases, Institute of Psychiatry, Psychology \& Neuroscience, King's College London, London, UK (E.C.S., H.C., P.R.H., J.H.); Department of Neurology, Guy's and St Thomas' NHS Foundation Trust, London, UK (A.N.); NIHR-Wellcome Trust King's Clinical Research Facility/SLaM Biomedical Research Centre, King's College Hospital, London, UK (J.H.)

Submission Type: Meta-analysis

Title Character Count: 87

Number of Tables: 5

Number of Figures: 3

Number of References: 61

Word Count of Abstract: 245

Word Count of Manuscript: 4977

Search terms: Migraine, EEG, Pediatric Headache, Sleep, Case control studies

Supplemental data: There are supplemental tables and figures with this manuscript.

Correspondence: Dr. Jan Hoffmann, jan.hoffmann@kcl.ac.uk, Headache Group,

Wellcome Foundation Building, Denmark Hill Campus, Institute of Psychiatry,

Psychology \& Neuroscience, King's College London, SE5 9PJ 


\section{Disclosure Statement}

Financial Disclosure: This work has been supported by the Medical Research

Council (PRH; MR/P006264/1), the Migraine Trust (JH and PRH), and by a Medical

Research Council PhD studentship (ECS; MR/N013700/1). JH is consulting for and/or serves on advisory boards of Allergan, Autonomic Technologies Inc.,

Cannovex BV, Chordate Medical AB, Eli Lilly, Hormosan Pharma, Lundbeck, Novartis, Sanofi and Teva. He has received honoraria for speaking from Allergan, Autonomic Technologies Inc., Chordate Medical AB, Novartis and Teva. He received personal fees for Medico-Legal Work as well as from Sage Publishing, Springer Healthcare and Quintessence Publishing. He receives research support from BristolMyers-Squibb. All these activities are unrelated to the submitted work. HC, and ADN report no financial disclosures related to the current work.

Non-financial Disclosure: none 
medRxiv preprint doi: https://doi.org/10.1101/2021.03.03.21252791; this version posted March 5, 2021. The copyright holder for this preprint (which was not certified by peer review) is the author/funder, who has granted medRxiv a license to display the preprint in perpetuity.

\section{Abstract}

2 Objectives: Sleep disturbance is often associated with migraine. However, there is a

3 paucity of research investigating objective and subjective measures of sleep in

4 migraineurs. This meta-analysis aims to determine whether there are differences in

5 subjective sleep quality measured using the Pittsburgh Sleep Quality Index (PSQI)

6 and objective sleep physiology measured using polysomnography between adult and

7 pediatric migraineurs, and healthy controls.

8 Methods: A systematic search of five databases was conducted to find case-

9 controlled studies which measured polysomnography and/or PSQI in migraineurs.

10 Effect sizes (Hedges' $g$ ) were entered into a random effects model meta-analysis.

11 Results: 32 separate studies were eligible. Overall, adult migraineurs had higher

12 PSQI scores than healthy controls $(g=0.75, p<.001)$. This effect was larger in

13 chronic than episodic migraineurs $(g=1.03, p<.001, g=0.63, p<.001$

14 respectively). For polysomnographic studies, adult and pediatric migraineurs

15 displayed a lower percentage of REM sleep $(g=-0.22, p=0.017, g=-0.71, p=$

160.025 respectively) than healthy controls. Pediatric migraineurs also displayed less

17 total sleep time $(g=-1.37, p=0.039)$, more wake $(g=0.52, p<.001)$ and shorter

18 sleep onset latency $(g=-0.37, p<.001)$ than healthy controls.

19 Conclusion: Migraineurs have significantly poorer subjective sleep quality, and

20 altered sleep compared to healthy individuals - a finding which is particularly evident

21 in children. This has implications for developing appropriate treatments. Further

22 longitudinal empirical studies are required to enhance our understanding of this

23 relationship. 
medRxiv preprint doi: https://doi.org/10.1101/2021.03.03.21252791; this version posted March 5, 2021. The copyright holder for this preprint (which was not certified by peer review) is the author/funder, who has granted medRxiv a license to display the preprint in perpetuity.

\section{1. Introduction}

25 It has long been recognized that there is a relationship between sleep and migraine.

26 This relationship is complex, as alterations in sleep can be a trigger, treatment, or

27 symptom of migraine ${ }^{1}$. There are an estimated one billion migraineurs globally, and

28 migraine is one of the leading causes of disability worldwide ${ }^{2}$, with a considerable

29 personal and socioeconomic burden ${ }^{3}$. To reduce this burden and meet the growing

30 clinical need ${ }^{4}$, a clearer understanding of the profile of sleep in migraineurs and its

31 relation to migraine-related disability is important, to enable clinicians to support

32 migraineurs and deliver targeted, effective sleep interventions ${ }^{5}$.

33 Despite its association there remains a paucity of research into sleep in migraineurs,

34 and there is no consensus on whether migraineurs exhibit objective changes in sleep

35 physiology. This is partly due to the small sample sizes of polysomnographic (PSG)

36 studies used to measure sleep. The current meta-analysis aims to overcome this by

37 aggregating data from multiple studies investigating differences in subjective sleep

38 quality as measured by the Pittsburgh Sleep Quality Index (PSQI) ${ }^{6}$, and objective

39 sleep physiology measured using PSG between migraineurs and healthy controls.

40 Furthermore, the relationship between measures of subjective sleep quality and

41 migraine disability was investigated by combining correlational data between PSQI

42 and Migraine Disability Assessment Test (MIDAS) scores ${ }^{7}$.

\section{2. Methods}

44 The format of this review followed the Preferred Reporting Items for Systematic

45 Reviews and Meta-analysis (PRISMA) guidelines ${ }^{8}$ and the PRISMA 2009 checklist

46 (Table e-1). The protocol for this review was pre-registered with PROSPERO

47 (registration number: CRD42020209325). 
medRxiv preprint doi: https://doi.org/10.1101/2021.03.03.21252791; this version posted March 5, 2021. The copyright holder for this preprint (which was not certified by peer review) is the author/funder, who has granted medRxiv a license to display the preprint in perpetuity.

\section{2.1. Search Strategy}

49 Two authors (ECS and HC) conducted an independent, electronic search of relevant

50 databases [Embase (1996 - 2020), MEDLINE® (1996 - 2020), Global Health (1973 -

51 2020), and APA PsycINFO (1806 - 2020), APA PsycArticles Full Text (2020)] from

52 their inception to the current date. Key search terms included combinations of

53 migraine, sleep*, PSQI, Pittsburgh Sleep Quality Index, polysomnograph*, PSG,

54 EEG, electroencephalograph*, MIDAS, HIT-6, MSQ with Boolean operators. The full

55 search strategy for OVID is displayed in Table e-2. The search was limited to studies

56 published in English and duplicates were removed. Titles and abstracts were

57 independently screened for eligibility by two authors (ECS and HC). Studies that

58 were eligible or if eligibility was unclear were submitted to the full text review stage.

59 Relevant studies were also retrieved from the reference lists of eligible studies. All

60 full texts were screened for eligibility by one reviewer (ECS) and $10 \%$ of the full texts

61 were selected randomly using a random number generator which the second

62 reviewer $(\mathrm{HC})$ then screened for eligibility. Any discrepancies were resolved with the

63 aid of another reviewer. All studies were examined to ensure they were independent

64 of one another. If full texts were not available, the original authors were contacted,

65 and the full texts were requested. The last search date was the 17 th of December

662020.

67 2.2. Inclusion Criteria

68 Studies were included which examined sleep quality as assessed by the PSQI

69 and/or physiological sleep variables using PSG in adult and pediatric migraineurs

70 and healthy control participants. Studies which computed correlations between

71 MIDAS and PSQI scores in migraineurs were also included. Review articles or 
medRxiv preprint doi: https://doi.org/10.1101/2021.03.03.21252791; this version posted March 5, 2021. The copyright holder for this preprint (which was not certified by peer review) is the author/funder, who has granted medRxiv a license to display the preprint in perpetuity.

72 single-case studies were not included. Studies which did not have a suitable healthy

73 control group were excluded.

\section{2.3. Population}

75 There were no restrictions on the age of the participants in the studies. However, for 76 analysis purposes, adults $\geq 18$ years of age and children $<18$ years of age were

77 included in separate analyses given that sleep physiology demonstrates age-

78 dependent quantitative differences ${ }^{9}$. Pregnant participants, and participants with

79 other headache disorders namely: cluster headache, tension type headache, and

80 medication over-use headache were not included in the analysis. However, a study

81 was included if it reported data which could be extracted that was specific to

82 migraineurs and no other headache disorders. Due to the limited number of studies

83 in this area, we deliberately kept the classification of migraine broad, thus

84 migraineurs with any diagnosis were included in this analysis: episodic, chronic,

85 migraine without aura (MO), migraine with aura (MA). Although this is not a standard

86 definition in the International Classification of Headache Disorders-3, studies which

87 also categorized their patients as sleep-related migraine (SRM), or non-sleep-related

88 migraine (NSRM) were included. Studies which categorized their patients by the

89 number of migraine or headache days per month, and not by episodic or chronic

90 were also included. In such cases, we categorized patients experiencing

91 headache/migraine on $\geq 15$ days per month as chronic and pooled them with the

92 other studies in chronic migraineurs. As sleep quality may differ between patients

93 with different frequencies of migraine, episodic and chronic migraine were analyzed

94 as subgroups in the meta-analysis of PSQI scores. 
medRxiv preprint doi: https://doi.org/10.1101/2021.03.03.21252791; this version posted March 5, 2021. The copyright holder for this preprint (which was not certified by peer review) is the author/funder, who has granted medRxiv a license to display the preprint in perpetuity.

\section{2.4. Outcome Measures}

96 To indicate whether migraineurs experience altered sleep, the primary outcomes

97 calculated were weighted effect sizes (Hedges' $g$ ) for the difference between

98 migraineurs and controls in global PSQI score and PSG-derived sleep measures.

99 The PSG-derived sleep measures were total sleep time (TST) in minutes, sleep

100 efficiency percent (SE), percent wake, percent of TST spent in REM sleep, non-REM

101 (NREM) sleep stage 1 (N1), stage 2 (N2), and stage 3 (N3), sleep onset latency

102 (SOL) in minutes. Secondly, to ascertain whether subjective sleep quality is related

103 to migraine disability the Fisher's $z$ transformed correlation coefficient between

104 MIDAS and PSQI scores in the migraine population was calculated.

\section{$105 \quad$ 2.5. Data Extraction}

106 Data extraction was performed using an a priori elaborated table in Microsoft Excel.

107 Extraction was completed by one author (ECS) and included: authors, year of publication, journal, publication type, database extracted from, participant demographics (mean age, sex ratio), migraine characterization, mean global PSQI score, PSG-derived sleep variable means, correlation coefficient between MIDAS and PSQI scores, standard deviations for each data point, and sample size. Where

112 the measures were not reported directly in the publication or the data were not in the

113 correct format for analysis (e.g., medians instead of means), the authors were

114 contacted to request this data. Studies which did not report data from which the

115 effect sizes could be calculated after contacting the authors, or if the authors did not respond were excluded. Further data were extracted that might be potential

117 moderators where appropriate. For example: the design of the study (e.g., matched, 118 or non-matched controls), whether the study excluded those on medication which 119 may affect the sleep cycle or those with co-morbid sleep disorders, and presence of 
medRxiv preprint doi: https://doi.org/10.1101/2021.03.03.21252791; this version posted March 5, 2021. The copyright holder for this preprint (which was not certified by peer review) is the author/funder, who has granted medRxiv a license to display the preprint in perpetuity.

a PSG adaptation night or not. If studies used older sleep scoring criteria to determine NREM sleep stages separately (stage 3 and stage 4 sleep), an average of the means for these two stages was computed to be comparable to updated AASM nomenclature: which defines these singularly as N3. If a study reported PSG sleep stage variables in minutes rather than percentages these were calculated manually based on the TST means available.

\subsection{Statistical Analysis}

127 Statistical analysis was performed using RStudio and the metafor package. The weighted effect sizes (Hedges' $g$ ) for each study were calculated using the means, sample size $(n)$ and standard deviations for each of the measures. Effect sizes were interpreted as small (0.2), medium (0.5) or large (0.8) in line with guidelines and were visualized using forest plots. The effect sizes were calculated such that a negative Hedges' $g$ value indicated that the controls had a higher score on that measure. For the PSQI analysis, studies which investigated chronic migraineurs were initially pooled with episodic migraineurs for a global analysis of effect size, however they were then analyzed in two separate sub-groups. For the sleep physiology analysis, PSG-derived variables from pediatric and adult migraineurs

137 were analyzed as two separate groups. Effect sizes were computed for each PSG 138 measure separately.

\subsubsection{Publication bias}

140 Publication bias refers to the over-inflation of effect sizes due to the tendency for

141 non-significant findings to remain unpublished. To assess this, Egger's regression

142 test for funnel plot asymmetry was performed. If the result is significant at $p<0.05$,

143 this provides evidence of publication bias. However, as Egger's test is prone to

144 producing false positives particularly with small numbers of studies, publication bias 
medRxiv preprint doi: https://doi.org/10.1101/2021.03.03.21252791; this version posted March 5, 2021. The copyright holder for this preprint (which was not certified by peer review) is the author/funder, who has granted medRxiv a license to display the preprint in perpetuity.

145 was also assessed by visual inspection of funnel plots. These plot a measure of 146 precision (standard error) against the observed effect size (Hedges' g). If the funnel

147 plots are substantially asymmetric, then publication bias can be assumed. Duval and

148 Tweedie's trim-and-fill method was used to assess whether there were any

149 unpublished studies missing from the analysis and estimate what the adjusted effect

150 size would be if these studies were present.

\section{$151 \quad$ 2.6.2. Between-studies heterogeneity}

152 As a meta-analysis typically includes studies of varying designs and populations, it is

153 important to quantify the proportion of between-studies heterogeneity to ensure

154 accurate estimation of the summary effect sizes. Cochran's $Q$ statistic is commonly

155 used to assess this. If $Q$ is significant at $p<0.05$ this indicates variability in the effect

156 sizes reported between studies. However, as this test has poor power to detect

157 heterogeneity when the meta-analysis includes a small number of studies the $I^{2}$

158 statistic was also calculated. An $l^{2}$ value of $0 \%$ represents no heterogeneity, $25 \%$

159 low, $50 \%$ moderate and $75 \%$ high. As heterogeneity was to be expected given the

160 variation in participant characteristics and experimental designs, a random-effects

161 model meta-analysis was conducted for all measures.

To explore potential sources of heterogeneity in both the PSQI and PSG analyses, where a significant effect size and moderate heterogeneity as indexed by an $I^{2}$ of $>50 \%$ were found, additional analyses were conducted by including characteristics of the study as moderator variables. The variables which were included as moderators were not predefined and were based on a previous meta-analysis ${ }^{10}$ : exclusion of participants with sleep disorders (yes/no), exclusion of participants taking drugs which affect the sleep cycle or a washout period before the study (yes/no), whether

169 the control population was matched for sex and age (yes/no). Where a study did not 
medRxiv preprint doi: https://doi.org/10.1101/2021.03.03.21252791; this version posted March 5, 2021. The copyright holder for this preprint (which was not certified by peer review) is the author/funder, who has granted medRxiv a license to display the preprint in perpetuity.

All rights reserved. No reuse allowed without permission.

170 state in the paper whether this was conducted or not, it was coded as 'no' for the

171 purposes of analysis.

$172 \quad$ 2.7. Data Availability Statement

173 The source data are available from the individual studies included. The extracted raw

174 data are available at Open Science Framework: https://osf.io/3t4u5/.

\section{3. Results}

\section{3.1. Description of Studies}

177 Results of the study selection process are displayed in Figure 1. From a total of 4089

178 studies after duplicates were removed, 183 were identified as potentially eligible after

179 screening the titles and abstracts. The full texts were then screened to confirm this,

180 after which 32 independent studies were included in the meta-analysis. Table 1

181 presents an overview of the studies included in the review. Twenty investigated

182 sleep quality in adults with and without migraine using the PSQI. Of these, 14 of

183 them had a population consisting of episodic migraineurs and 6 of them chronic

184 migraineurs. Four studies (two already included in the PSQI analysis) reported the

185 correlation between MIDAS and PSQI scores in migraineurs ${ }^{11-14}$. There were no

186 participants $<18$ years of age in the PSQI analysis or the MIDAS and PSQI

187 correlational analysis due to a lack of available data. Eleven studies measured PSG

188 in adults ${ }^{15-20}$ and children ${ }^{21-25}$, with and without migraine. One study ${ }^{16}$ compared $^{1}$

189 migraineurs PSG in the pre-, mid- and post-ictal phase, and thus it was not

190 appropriate to extract a single value for this data. However, they provided a pooled

191 value for the PSQI analysis, and thus it was excluded from the PSG analysis only. 
medRxiv preprint doi: https://doi.org/10.1101/2021.03.03.21252791; this version posted March 5, 2021. The copyright holder for this preprint (which was not certified by peer review) is the author/funder, who has granted medRxiv a license to display the preprint in perpetuity. All rights reserved. No reuse allowed without permission.

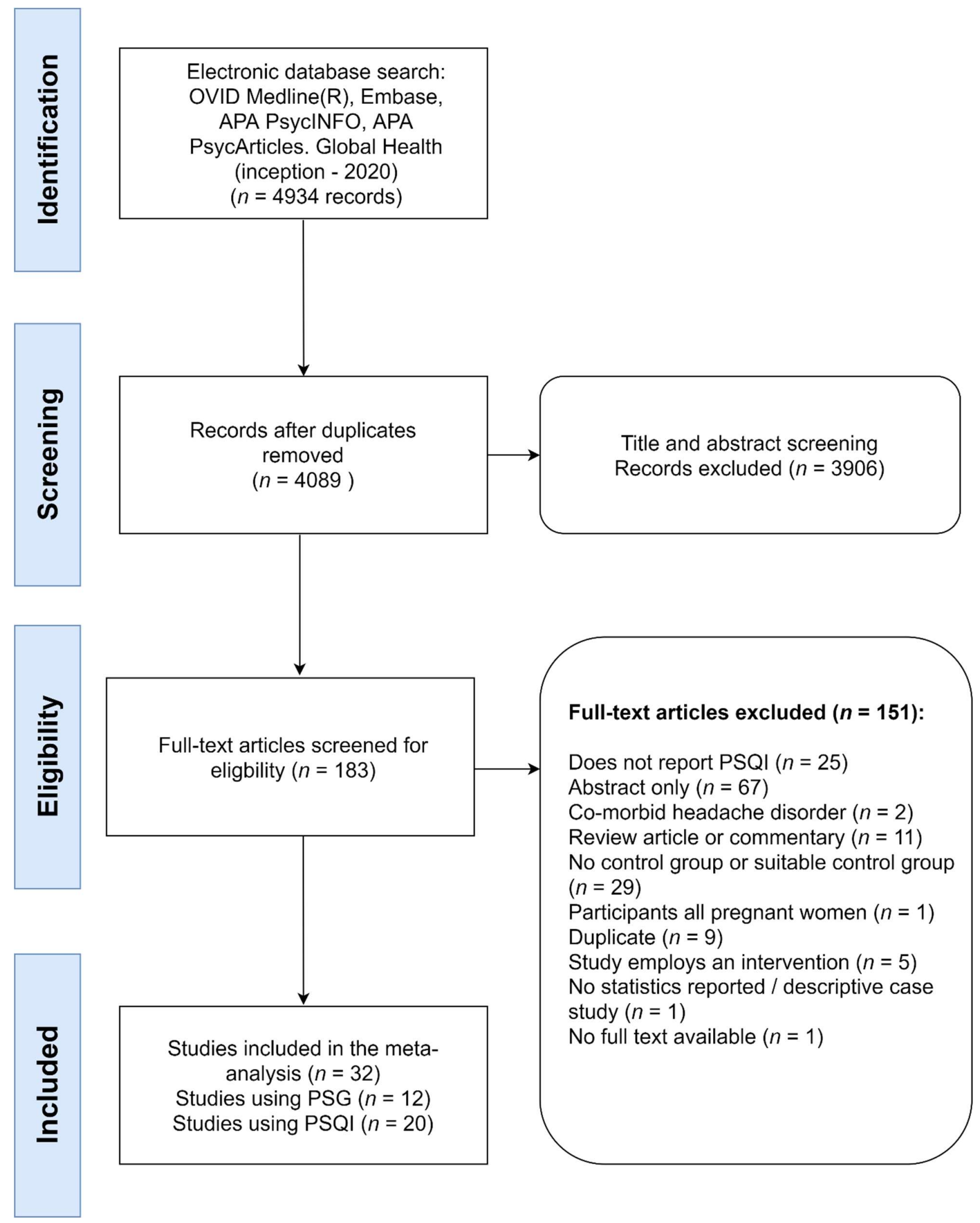

195 Figure 1: PRISMA flow diagram depicting the stages of study selection. Abbreviations: PSQI, 196 Pittsburgh Sleep Quality Index; PSG, polysomnography; MIDAS, Migraine Disability 197 Assessment. 
medRxiv preprint doi: https://doi.org/10.1101/2021.03.03.21252791; this version posted March 5, 2021. The copyright holder for this preprint (which was not certified by peer review) is the author/funder, who has granted medRxiv a license to display the preprint in perpetuity.

$199 \quad$ 3.2. Risk of publication bias results

200 There was no indication of publication bias for any of the analyses apart from the 201 PSQI and MIDAS correlation analysis as indicated by Egger's test for funnel plot 202 asymmetry (see Table e-3). The trim-and-fill method estimated that there was one 203 study missing on the right-hand side, and this would increase the overall effect size 204 to significance but not change the direction of effect $(z=0.44, p=0.024)$. Although

205 Egger's test was not significant for any of the other analyses, visual inspection of the 206 funnel plots was completed. For the PSG analysis, visual inspection, and the trim207 and-fill method (see Figure e-1), revealed that for percentage wake there was likely to be one study missing on the right. However, adjustment of the effect size did not 209 change the direction of overall effect or reduce the effect size, thus publication bias 210 is unlikely to influence the result.

\section{$211 \quad$ 3.3. Meta-analysis results}

\section{3.3.1. PSQI score}

213 Figure 2 displays the forest plot of individual study-level as well as the overall effect

214 size for the PSQI scores analysis in adult migraineurs and controls. Overall, there 215 was a medium effect size for the difference in PSQI scores between migraineurs and 216 healthy controls $(g=0.75, p<.001)$. For the chronic sub-group there was a large 217 significant effect size $(g=1.03, p<.001)$ and for the episodic sub-group there was a 218 medium effect size $(g=0.63, p<.001)$. The direction of these effect sizes indicates 219 that migraineurs scored significantly higher on the PSQI than healthy controls, 220 suggesting poorer sleep quality.

221 For the overall analysis and the episodic subgroup there was statistically significant 222 heterogeneity as evidenced by Cochran's Q statistic (161.6 and 105.5, respectively). 223 The chronic sub-group analysis had significantly lower heterogeneity (20.32) as 
medRxiv preprint doi: https://doi.org/10.1101/2021.03.03.21252791; this version posted March 5, 2021. The copyright holder for this preprint

(which was not certified by peer review) is the author/funder, who has granted medRxiv a license to display the preprint in perpetuity.

All rights reserved. No reuse allowed without permission.

224 measured by Cochran's $Q$. However, when considering the $I^{2}$ statistic the studies

225 within the total, episodic, and chronic analyses all displayed moderate-high

226 heterogeneity $\left(I^{2}=90.8 \%, 91.6 \%, 76.7 \%\right.$ respectively $)$, suggesting that over $70 \%$ of

227 the variability is attributable to between-study heterogeneity, over and above

228 sampling error.

229 As there was moderate or greater heterogeneity, moderator analyses were

230 conducted on the overall analysis (see Table 4). There was a negative moderating

231 effect of whether the study excluded those with sleep disorders or not $\left(Q_{M}=7.40, p\right.$

$232=.007, \beta=-0.81$ ), suggesting that when sleep disorders were excluded the effect

233 size is smaller. However, there was significant heterogeneity not explained by this

234 moderator $\left(Q_{E}=114.61, p<.001\right)$, and as only two studies excluded those with

235 sleep disorders this could have skewed the result. No other variables were

236 significant moderators. 
medRxiv preprint doi: https://doi.org/10.1101/2021.03.03.21252791; this version posted March 5, 2021. The copyright holder for this preprint (which was not certified by peer review) is the author/funder, who has granted medRxiv a license to display the preprint in perpetuity.

All rights reserved. No reuse allowed without permission.

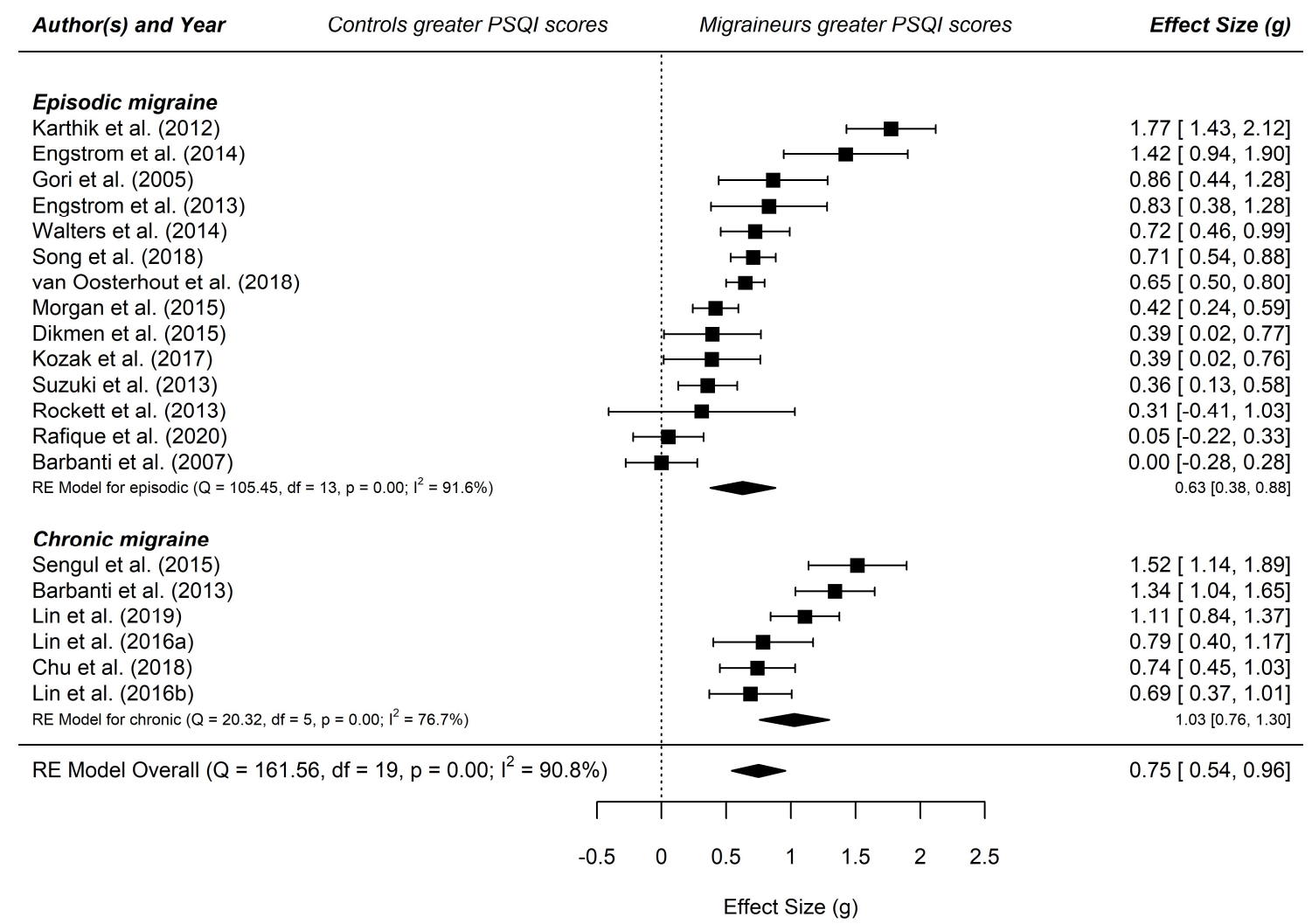

238 Figure 2: Forest plot of the meta-analysis of PSQI scores in migraineurs and controls.

239 Abbreviations: PSQI, Pittsburgh Sleep Quality Index; RE, random effects. The standardized

240 mean difference (Hedges' $g$ ) and confidence intervals for the difference in global PSQI scores

241 is shown between migraineurs and healthy controls.

242 3.3.2. Polysomnography - adult \& pediatric

243 Table 2 displays the effect sizes and heterogeneity measures for the PSG-derived

244 sleep parameters in adult migraineurs and healthy controls. There was a significant

245 small effect size for percentage REM sleep $(g=-0.22, p=0.017)$. The direction of

246 this effect indicates that the adult migraineurs had less REM sleep than controls.

247 There were no statistically significant effect sizes for the other parameters. There

248 was significantly moderate heterogeneity as evidenced by the $Q$ and $I^{2}$ statistic in 
medRxiv preprint doi: https://doi.org/10.1101/2021.03.03.21252791; this version posted March 5, 2021. The copyright holder for this preprint (which was not certified by peer review) is the author/funder, who has granted medRxiv a license to display the preprint in perpetuity.

249 two of the analyses (SE and wake). However, as the main measure of effect size on

250 these parameters was not significant no moderator analyses were conducted.

251 Table 3 displays the effect sizes for the PSG-derived parameters in pediatric

252 migraineurs. There were small significant effect sizes for wake ( $g=0.43, p=0.015)$

253 and SOL $(g=-0.37, p<.001)$. There was a medium significant effect size for REM

254 sleep $(g=-0.71, p=0.025)$, and a large significant effect size for TST $(g=-1.37, p=$

255 0.039). The direction of these effects indicates that pediatric migraineurs had more

256 wake, less REM sleep, less TST and longer SOL than healthy controls. There was

257 statistically significant heterogeneity in six of the analyses (TST, SE, N1, N2, N3,

258 REM).

259 Two of the analyses of PSG variables in pediatric migraineurs which found

260 significant effect sizes and displayed at least moderate heterogeneity were: TST and

261 REM, thus a moderator analysis was conducted on these. None of the studies

262 excluded patients with sleep disorders, so this was not included as a moderating

263 variable. Table 5 displays the results. For TST, both whether the study excluded

264 patients who were on sleep-affecting medications, and whether the study included

265 matched controls or not, were significant moderating variables $\left(Q_{M}=19.6, p<.001\right.$,

$\left.266 Q_{M}=19.6, p<.001\right)$ respectively. The test for residual heterogeneity $\left(Q_{E}\right)$ was not

267 significant for these two analyses, indicating that they are largely influencing the

268 effect size in these studies. The direction of this moderator analysis indicated that

269 when a study did exclude those on medication, or did include matched controls, the

270 effect size was smaller. However, whether the study included an adaptation night or

271 not was not a significantly moderating variable $\left(Q_{M}=0.20, p=0.655, Q_{E}=38.46, p<\right.$

272 .001). For REM sleep, there were no significant moderators of effect size and $Q_{E}$

273 was significant for all analyses, indicating significant residual heterogeneity that 
medRxiv preprint doi: https://doi.org/10.1101/2021.03.03.21252791; this version posted March 5, 2021. The copyright holder for this preprint (which was not certified by peer review) is the author/funder, who has granted medRxiv a license to display the preprint in perpetuity.

All rights reserved. No reuse allowed without permission.

274 cannot be explained by these moderators, and thus other variables are influencing

275 between-study heterogeneity.

276 3.3.3. Relationship between sleep quality and migraine disability

277 Figure 3 shows the weighted effect size for the correlation between MIDAS and PSQI

278 scores in migraineurs. There was a small non-significant effect size for the

279 correlation between MIDAS scores and PSQI scores in migraineurs $(z=0.32, p=$

280 0.060), thus suggesting from this analysis that there is no relationship between sleep

281 quality and migraine disability. There was significantly low heterogeneity between

282 studies as indicated by Cochran's $Q$ statistic $(Q=28.74, p<.001)$, however $I 2 \%$

283 indicated high heterogeneity $(I 2 \%=91.1 \%)$, and as this statistic is more appropriate

284 for small samples, high heterogeneity between these studies can be assumed. As

285 the main analysis was not significant no moderator analyses were conducted.

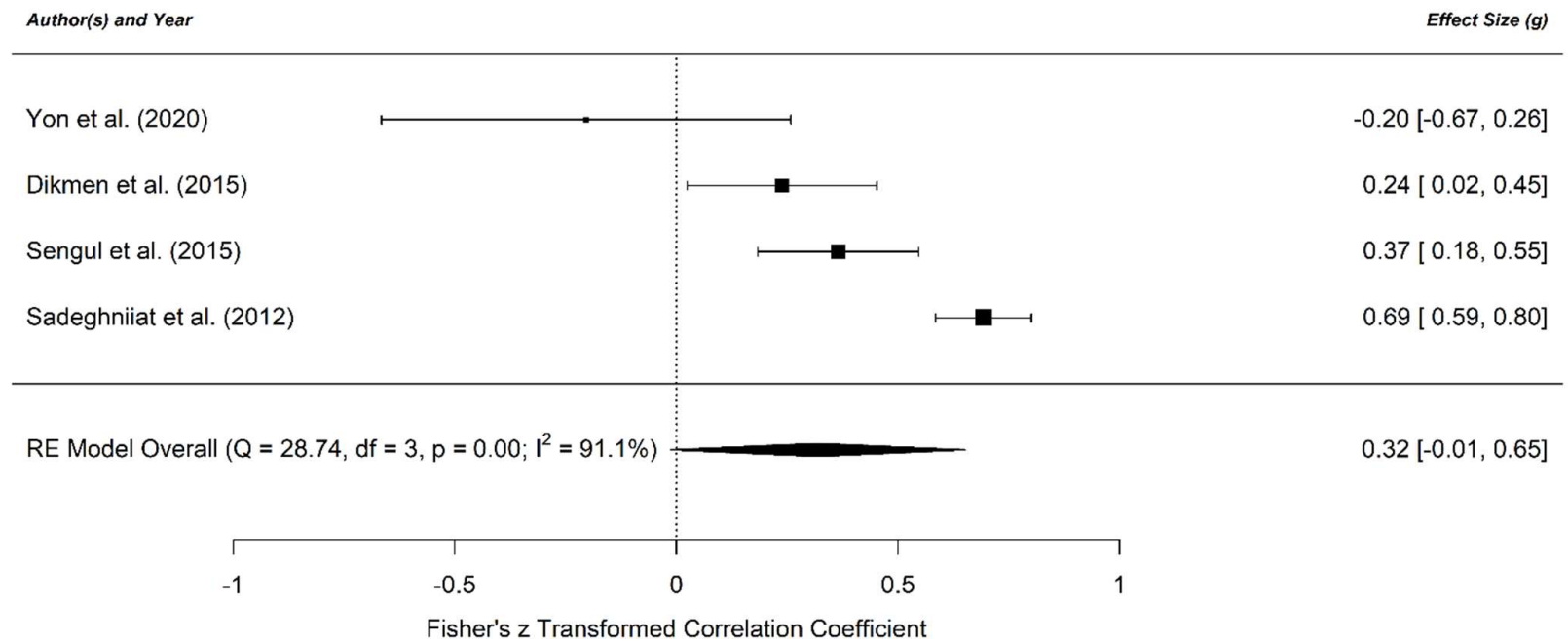

Figure 3: Forest plot of the meta-analysis of MIDAS and PSQI correlations. Abbreviations:

$\mathrm{RE}$, random effects. The Fisher's $\mathrm{z}$ transformed correlation coefficient is shown between MIDAS scores and PSQI scores in patients with migraine across four studies. 
medRxiv preprint doi: https://doi.org/10.1101/2021.03.03.21252791; this version posted March 5, 2021. The copyright holder for this preprint (which was not certified by peer review) is the author/funder, who has granted medRxiv a license to display the preprint in perpetuity.

\section{4. Discussion}

292 This meta-analysis aimed to consolidate previous findings and establish whether

293 there are differences in subjective sleep quality and objective sleep physiology

294 between migraineurs and healthy individuals. The findings demonstrate that

295 migraineurs display significantly higher scores on the PSQI indicating worse

296 subjective sleep quality than healthy controls, an effect which is larger in those with

297 chronic rather than episodic migraine. There are differences in objective sleep

298 physiology, although this is mainly evident in the pediatric population. For example,

299 adult and pediatric migraineurs have significantly less REM sleep as a percentage of

300 TST than healthy individuals, and this effect size is larger in the pediatric population.

301 Pediatric migraineurs also exhibit significantly less TST, shorter SOL, and more

302 wake than healthy controls. There were no differences between migraineurs and

303 healthy controls in any other sleep parameters either in adult or pediatric

304 populations. Finally, there was no significant overall correlation between PSQI and

305 MIDAS scores in migraineurs.

\section{$306 \quad$ 4.1. Subjective sleep quality}

307 These findings extend the current literature by aggregating the results of multiple

308 studies, thereby increasing power. They demonstrate that sleep quality is worse in

309 migraineurs than healthy individuals. Although the PSQI may be criticized as a

310 subjective measure of sleep, it has been shown to have high test-retest reliability and

311 high validity ${ }^{26}$. Moreover, this finding is not surprising; poor sleep is reported as an

312 exacerbating factor for migraines in $50 \%$ of cases $^{27}$. The effect size was larger in

313 chronic migraineurs. This is in line with previous research where poor sleep has

314 been shown to be an important factor in progression to chronic migraine ${ }^{28}$. 
medRxiv preprint doi: https://doi.org/10.1101/2021.03.03.21252791; this version posted March 5, 2021. The copyright holder for this preprint (which was not certified by peer review) is the author/funder, who has granted medRxiv a license to display the preprint in perpetuity.

\section{4.2. Polysomnography}

316 PSG on the other hand provides a more objective measure of sleep. This analysis

317 found that REM sleep is reduced in both adult and pediatric migraineurs, relative to

318 healthy individuals, aligned with previous associations between migraine and REM

319 sleep. For example, a co-association between narcolepsy type 1 (NT1) and migraine

320 has been demonstrated ${ }^{29}$ and migraine is reported as a risk factor for progression to

321 NT1 in children ${ }^{30}$. Moreover, one study reported an association between dream

322 enactment behavior during REM sleep and migraine ${ }^{31}$. Furthermore, cutaneous

323 allodynia, a prominent symptom experienced during migraine attacks, has been

324 shown to worsen in response to REM sleep deprivation in preclinical pain models ${ }^{32}$.

325 This indicates a potential dysfunction in mechanisms underlying REM-NREM or

326 REM-wake transitions in migraineurs. A plausible neural correlate for this is the

327 hypothalamic orexinergic system which plays a critical role in stabilizing sleep/wake

328 transitions and REM sleep ${ }^{34}$, and has been linked to migraine, suggesting multiple

329 points of intersection between sleep and trigeminal pain. Although, this is

330 speculative, and the relationship with REM sleep is likely to be complex and bi-

331 directional. For example, some preventative treatments for migraine can suppress

332 REM sleep whilst others lead to increased arousals during REM.

333 There were no differences between adult migraineurs and controls in any other sleep

334 parameters. This is at odds with a previous meta-analysis which found that TST,

335 WASO and SOL were worse in those with chronic pain (including migraineurs) than

336 healthy controls ${ }^{10}$. Although, this might be reconciled in that the number of studies

337 they included was larger and contained heterogeneous chronic pain conditions. It is

338 likely that with a greater number of studies, we might see significant differences in

339 wake, TST, and SOL in adults. 
medRxiv preprint doi: https://doi.org/10.1101/2021.03.03.21252791; this version posted March 5, 2021. The copyright holder for this preprint (which was not certified by peer review) is the author/funder, who has granted medRxiv a license to display the preprint in perpetuity.

340 Conversely, pediatric migraineurs displayed lower TST, lower REM sleep

341 percentage, and more wake in line with previous findings in pediatric patients with

342 chronic pain ${ }^{35}$. The migraineurs also displayed shorter SOL than controls. This is

343 suggestive of pediatric migraineurs operating at higher sleep pressure due to being

344 chronically sleep deprived (perhaps due to headache, behavior, or both) hence their

345 shorter SOL times. Alternatively, migraineurs may be biologically sleepier than their

346 healthy counterparts. Their shorter SOL is at odds with an actigraphy study in

347 pediatric migraineurs which found a longer SOL in patients compared to healthy

348 controls $^{36}$. However, actigraphy is widely considered to be less accurate than PSG,

349 particularly for $\mathrm{SOL}^{37}$.

350 The lack of any significant difference in NREM sleep, including N3, in both adults

351 and children with migraine compared to controls is noteworthy, although this

352 represents macroscopic sleep EEG scoring rather than quantitative EEG analysis.

353 Indeed, deficits in NREM sleep can be compensated for by an increase in sleep

354 intensity rather than duration as is the case typically for REM sleep ${ }^{38}$, which would

355 not be apparent with macroscopic scoring.

\section{4.3. Migraine disability}

357 The lack of a significant correlation between PSQI and MIDAS scores is surprising

358 given that previous studies report significant correlations between migraine-related

359 disability and sleep disturbances ${ }^{39}$, and altering sleep (e.g. by switching back to day

360 shifts from night shifts) can have a profound effect on migraine-related disability

361 scores $^{40}$. This may reflect the small number of studies and the high heterogeneity

362 between them. Three of the studies in this analysis found significant positive

363 correlations ${ }^{14}$, and one found a large negative correlation ${ }^{11}$. Studies with a small $n$

364 can lead to inflated effect sizes ${ }^{41}$. Indeed, the study which found a negative 
medRxiv preprint doi: https://doi.org/10.1101/2021.03.03.21252791; this version posted March 5, 2021. The copyright holder for this preprint (which was not certified by peer review) is the author/funder, who has granted medRxiv a license to display the preprint in perpetuity.

365 relationship had an $n$ of $21^{11}$, compared to 332 for one of the larger studies, thus

366 potentially skewing the results towards insignificance. There was also evidence of

367 publication bias within this analysis. Although, caution should be taken when

368 interpreting the results as despite meta-analysis being theoretically sound on a small

369 number of studies, Egger's test can produce false positives.

\section{$370 \quad$ 4.4. Limitations}

371 A critical consideration is that many migraineurs are given prophylactic treatments

372 which can affect the sleep cycle. When this factor was included as a moderating

373 variable in the pediatric analysis for TST and REM sleep, studies which excluded

374 those on medications had a smaller effect size for TST than those which did not,

375 suggesting that the patient's medication may be contributing to differences in TST.

376 Indeed, beta-blockers - a common migraine preventative, are known to reduce TST.

377 Nonetheless, significant residual heterogeneity remained between studies which

378 could not be explained by this moderator, suggesting other factors are at play.

379 Importantly, medication exclusion did not impact REM sleep. Although, it is unclear

380 whether medication was driving the REM sleep effect seen in adults as no moderator

381 analysis was conducted on this. Furthermore, for many studies it was impossible to

382 deduce whether patients on medication were excluded. Future studies should ensure

383 accurate reporting of exclusion criteria.

384 These results do not provide evidence for a direct functional relationship between

385 migraine and sleep regulation. Are migraineurs experiencing poor sleep due to the

386 pain caused by attacks, or are they experiencing attacks due to poor sleep? The

387 studies in this analysis did not report whether the migraineurs typically experience

388 their migraine attacks during sleep itself, despite two thirds of migraineurs reporting

389 experiencing them during sleep ${ }^{27}$. Only a handful of studies reported whether the 
medRxiv preprint doi: https://doi.org/10.1101/2021.03.03.21252791; this version posted March 5, 2021. The copyright holder for this preprint (which was not certified by peer review) is the author/funder, who has granted medRxiv a license to display the preprint in perpetuity.

390 PSG was conducted in the ictal or inter-ictal period, despite this being shown to have 391 a considerable effect on objective measures of sleep ${ }^{42}$. If this were to affect the 392 results however, we might have expected to see a difference in other sleep 393 parameters in both the adults and pediatric migraineurs. As we only see the 394 decrease specific to REM sleep and no other sleep stages, this implies a specific 395 dysfunction in the mechanisms that underly REM sleep.

396 Alternatively, the reduced REM sleep could reflect the finding that many migraine 397 attacks occur in the early hours of the morning - the portion of the night where REM 398 sleep dominates, hence curtailing REM opportunity. However, two of the PSG 399 studies in the current analysis had a population of migraineurs with predominantly 400 sleep-related attacks ${ }^{16,20}$ and neither study reported differences in REM sleep 401 between SRM, NSRM or controls. This implies that the decrease in REM sleep we 402 see here is not necessarily due to arousals from REM sleep during an attack.

403 Moreover, six of the included studies did not include an adaptation night to the sleep 404 laboratory. The 'first night effect' has been shown to particularly affect measures of 405 REM sleep ${ }^{43}$. However, the moderator analyses in pediatric migraineurs found that 406 whether the study included an adaptation night or not was not a significant 407 moderator of the overall effect size for REM sleep or TST.

408 The disparity between the large effect size seen with the subjective measure of sleep 409 and the lack of significant difference between migraineurs and controls with all but 410 one of the objective sleep physiology parameters in the adult population is not 411 unexpected. Global PSQI scores have been shown not to significantly correlate with 412 sleep variables as measured via PSG ${ }^{44}$. As we did not analyze PSQI scores in the 413 pediatric population, it is not clear if pediatric migraineurs also experience altered 
medRxiv preprint doi: https://doi.org/10.1101/2021.03.03.21252791; this version posted March 5, 2021. The copyright holder for this preprint (which was not certified by peer review) is the author/funder, who has granted medRxiv a license to display the preprint in perpetuity.

414 subjective sleep quality. This being said, the PSQI has been shown to have limited 415 utility in pediatrics ${ }^{45}$.

416 In addition, many of the studies were retrospective studies of patients who have

417 previously been referred to the sleep clinic with non-specific sleep complaints,

418 necessitating PSG assessment, suggesting the migraineurs referred may already

419 report underlying sleep complaints. Few of the studies mentioned prior sleep history

420 in relation to PSG, and for subjective sleep quality those which did exclude sleep

421 disorders had a smaller effect size than those which did not, suggesting that poor

422 sleep quality may be attributable to undiagnosed concurrent sleep disorders.

423 However, this is unlikely to be the case as the heterogeneity between studies was

424 not fully explained by this variable. This residual heterogeneity may reflect

425 differences in pre-recording sleep history, differing recording environments,

426 techniques and equipment, as well as differences in inter-scorer scoring

427 concordance ${ }^{46}$.

\section{4.5. Clinical implications}

429 These findings highlight that consideration of patient sleep should play an integrated

430 role in the assessment and treatment of migraine. Clinicians should consider

431 prioritizing behavioral sleep interventions (especially in children with migraine) as

432 well as considering sleep when prescribing medication. Recent studies have

433 demonstrated the utility of sleep behavioral interventions in reverting chronic to

434 episodic migraine ${ }^{47}$, which may suggest a potential role of instigating similar

435 interventions earlier in the natural history of the disorder to mitigate the risk of

436 conversion from episodic to chronic migraine. The relevance of REM sleep and its

437 modulation for migraine and migraine treatment is again emphasized by this meta-

438 analysis. The relationship is likely to be complex and related to sleep (and indeed 
medRxiv preprint doi: https://doi.org/10.1101/2021.03.03.21252791; this version posted March 5, 2021. The copyright holder for this preprint (which was not certified by peer review) is the author/funder, who has granted medRxiv a license to display the preprint in perpetuity.

All rights reserved. No reuse allowed without permission.

439 REM) homeostasis, rather than related to any absolute proportions of REM sleep, a

440 notion supported by the REM suppressing (rather than enhancing) effects of the

441 best-known migraine preventive, amitriptyline.

\section{4.6. Conclusions}

443 Migraineurs report poorer subjective sleep quality than healthy individuals, an effect

444 larger in those with chronic migraines. Adult migraineurs exhibit significantly less

445 REM sleep compared to healthy controls. Pediatric migraineurs also show

446 significantly reduced sleep time, faster sleep onset and more wake than controls.

447 The interplay between migraine and sleep is likely to be highly complex and remains

448 poorly understood. However, the findings of this meta-analysis highlight the

449 importance of assessing and treating sleep in migraineurs as an integrated part of

450 headache treatment. While offering significant insight into how sleep is relevant to

451 migraine, this study also highlights the limitations of drawing conclusions from small

452 case-controlled PSG studies of patients with migraine given the significant number of

453 confounds and heterogeneity involved. Future studies may do well to analyze the

454 interplay between migraine and subjective sleep factors at large-scale population-

455 based levels, as well as also using a more population-based approach to sleep

456 physiological studies, performed in a standardized way, to minimize variability where

457 possible.

458

459

460

461 
medRxiv preprint doi: https://doi.org/10.1101/2021.03.03.21252791; this version posted March 5, 2021. The copyright holder for this preprint (which was not certified by peer review) is the author/funder, who has granted medRxiv a license to display the preprint in perpetuity. All rights reserved. No reuse allowed without permission.

\section{Appendix - Authors}

\begin{tabular}{|c|c|c|c|}
\hline Name & Location & Role & Contribution \\
\hline Emily C. Stanyer, MPsych & $\begin{array}{l}\text { King's College London, United } \\
\text { Kingdom }\end{array}$ & Author & $\begin{array}{l}\text { Designed and conceptualized the } \\
\text { study; collected, performed statistical } \\
\text { analyses, interpreted the data; and } \\
\text { drafted and revised the manuscript } \\
\text { for intellectual content }\end{array}$ \\
\hline Hannah Creeney, MSc & $\begin{array}{l}\text { King's College London, United } \\
\text { Kingdom }\end{array}$ & Author & Major role in the acquisition of data \\
\hline $\begin{array}{l}\text { Alexander D. Nesbitt, BM } \\
\text { BCh, PhD }\end{array}$ & $\begin{array}{l}\text { Guy's and St Thomas' NHS } \\
\text { Foundation Trust, London, } \\
\text { United Kingdom }\end{array}$ & Author & $\begin{array}{l}\text { Revised the manuscript for } \\
\text { intellectual content }\end{array}$ \\
\hline Philip R. Holland, PhD & $\begin{array}{l}\text { King's College London, United } \\
\text { Kingdom }\end{array}$ & Author & $\begin{array}{c}\text { Revised the manuscript for } \\
\text { intellectual content }\end{array}$ \\
\hline Jan Hoffmann, MD, PhD & $\begin{array}{l}\text { King's College London, United } \\
\text { Kingdom }\end{array}$ & Author & $\begin{array}{l}\text { Designed and conceptualized the } \\
\text { study; interpreted the data; revised } \\
\text { the manuscript for intellectual content }\end{array}$ \\
\hline
\end{tabular}

463

464

465

466

467 
medRxiv preprint doi: https://doi.org/10.1101/2021.03.03.21252791; this version posted March 5, 2021. The copyright holder for this preprint (which was not certified by peer review) is the author/funder, who has granted medRxiv a license to display the preprint in perpetuity.

\section{References}

470 1. Kelman L. The triggers or precipitants of the acute migraine attack. Cephalalgia. $471 \quad 2007 ; 27: 394-402$.

472 2. Stovner LJ, Nichols E, Steiner TJ, et al. Global, regional, and national burden of 473

474

475 migraine and tension-type headache, 1990-2016: a systematic analysis for the Global Burden of Disease Study 2016. The Lancet Neurology. 2018;17:954976.

476

477

3. Deuschl G, Beghi E, Fazekas F, et al. The burden of neurological diseases in Europe: an analysis for the Global Burden of Disease Study 2017. The Lancet Public Health. 2020;5:e551-e567.

479

480

4. Diener H-C, Charles A, Goadsby PJ, Holle D. New therapeutic approaches for the prevention and treatment of migraine. The Lancet Neurology.

481 2015;14:1010-1022.

482

483

484

485

486

5. Bellesi M, Riedner BA, Garcia-Molina GN, Cirelli C, Tononi G. Enhancement of sleep slow waves: underlying mechanisms and practical consequences. Front Syst Neurosci [online serial]. Frontiers; 2014;8. Accessed at: https://www.frontiersin.org/articles/10.3389/fnsys.2014.00208/full. Accessed January 23, 2021.

487

488

489

6. Buysse DJ, Reynolds CF, Monk TH, Berman SR, Kupfer DJ. The Pittsburgh sleep quality index: A new instrument for psychiatric practice and research. Psychiatry Research. 1989;28:193-213.

490

491

492

7. Stewart WF, Lipton RB, Dowson AJ, Sawyer J. Development and testing of the Migraine Disability Assessment (MIDAS) Questionnaire to assess headacherelated disability. Neurology. AAN Enterprises; 2001;56:S20-S28.

493

494

495

8. Moher D, Liberati A, Tetzlaff J, Altman DG, Group TP. Preferred Reporting Items for Systematic Reviews and Meta-Analyses: The PRISMA Statement. PLOS Medicine. Public Library of Science; 2009;6:e1000097.

496

497

9. Vitiello MV. Sleep in Normal Aging. Sleep Medicine Clinics. Elsevier; 2006;1:171-176.

498

499

500

10. Mathias JL, Cant ML, Burke ALJ. Sleep disturbances and sleep disorders in adults living with chronic pain: a meta-analysis. Sleep Medicine. 2018;52:198210.

501

502

503

11. Yon MI, Gumusyayla S, Vural G. Sleep quality and frequency of comorbidities and its relation with chronic migraine related disability in patients with chronic migraine. Annals of Medical Research. 2020;27:45-51.

12. Dikmen PY, Yavuz BG, Aydinlar El. The relationships between migraine, depression, anxiety, stress, and sleep disturbances. Acta Neurologica Belgica. Springer; 2015;115:117-122. 
medRxiv preprint doi: https://doi.org/10.1101/2021.03.03.21252791; this version posted March 5, 2021. The copyright holder for this preprint (which was not certified by peer review) is the author/funder, who has granted medRxiv a license to display the preprint in perpetuity.

507

508

509

510

511

512

513

514

515

516

517

518

519

520

521

522

523

524

525

526

527

528

529

530

531

532

533

534

535

536

537

538

539

540

541

542

543

13. Sengul Y, Sengul HS, Bakim B, Yucekaya SK, Yucel S, Akgun M. Sleep disturbances and excessive daytime sleepiness in migraine: A comparison between comorbidities and disability. Sleep Biol Rhythms. 2015;13:76-84.

14. Sadeghniiat K, Rajabzadeh A, Ghajarzadeh M, Ghafarpour M. Sleep quality and depression among patients with migraine. Acta Medica Iranica. Epub 2013.:784-788.

15. Marca GD, Vollono C, Rubino M, Trapani GD, Mariotti P, Tonali P. Dysfunction of Arousal Systems in Sleep-Related Migraine Without Aura. Cephalalgia. SAGE Publications Ltd STM; 2006;26:857-864.

16. Engstrøm M, Hagen K, Bjørk M, Gravdahl GB, Sand T. Sleep-related and nonsleep-related migraine: interictal sleep quality, arousals and pain thresholds. The Journal of Headache and Pain. 2013;14:68.

17. Karthik N, Sinha S, Taly AB, Kulkarni GB, Ramachandraiah CT, Rao S. Alteration in polysomnographic profile in 'migraine without aura' compared to healthy controls. Sleep Medicine. 2013;14:211-214.

18. Kristiansen HA, Kværner KJ, Akre H, Øverland B, Russell MB. Migraine and sleep apnea in the general population. The Journal of Headache and Pain. Springer; 2011;12:55-61.

19. Nayak C, Sinha S, Nagappa M, et al. Study of sleep microstructure in patients of migraine without aura. Sleep Breath. 2016;20:263-269.

20. Vollono Catello, Gnoni Valentina, Testani Elisa, et al. Heart Rate Variability in Sleep-Related Migraine without Aura. Journal of Clinical Sleep Medicine. American Academy of Sleep Medicine; 09:707-714.

21. Roccella M, Marotta R, Operto FF, et al. NREM sleep instability in pediatric migraine without aura. Frontiers in neurology. Frontiers; 2019;10:932.

22. El-Heneedy YAE, Bahnasy WS, ELAhwal SA, Amer RAR, Abohammar SDA, Salem HAM. Psychiatric and sleep abnormalities in school-age children with migraine. Egypt J Neurol Psychiatry Neurosurg. 2019;55:16.

23. Esposito $M$, Parisi $P$, Miano $S$, Carotenuto $M$. Migraine and periodic limb movement disorders in sleep in children: a preliminary case-control study. J Headache Pain. 2013;14:57.

24. Masuko AH, Villa TR, Pradella-Hallinan M, et al. Prevalence of bruxism in children with episodic migraine - a case-control study with polysomnography. BMC Res Notes. 2014;7:298.

25. Armoni Domany $\mathrm{K}$, Nahman-Averbuch $\mathrm{H}$, King CD, et al. Clinical presentation, diagnosis and polysomnographic findings in children with migraine referred to sleep clinics. Sleep Medicine. 2019;63:57-63. 
medRxiv preprint doi: https://doi.org/10.1101/2021.03.03.21252791; this version posted March 5, 2021. The copyright holder for this preprint (which was not certified by peer review) is the author/funder, who has granted medRxiv a license to display the preprint in perpetuity.

544

545

546

547

548

549

550

551

552

553

554

555

556

557

558

559

560

561

562

563

564

565

566

567

568

569

570

571

572

573

574

575

576

577

578

579

580

581

582

26. Backhaus J, Junghanns K, Broocks A, Riemann D, Hohagen F. Test-retest reliability and validity of the Pittsburgh Sleep Quality Index in primary insomnia. Journal of Psychosomatic Research. 2002;53:737-740.

27. Kelman L, Rains JC. Headache and Sleep: Examination of Sleep Patterns and Complaints in a Large Clinical Sample of Migraineurs. Headache: The Journal of Head and Face Pain. 2005;45:904-910.

28. Bigal ME, Lipton RB. What predicts the change from episodic to chronic migraine? Current Opinion in Neurology. 2009;22:269-276.

29. Dahmen N, Kasten M, Wieczorek S, Gencik M, Epplen J, Ullrich B. Increased Frequency of Migraine in Narcoleptic Patients: A Confirmatory Study.

Cephalalgia. 2003;23:14-19.

30. Yang C-P, Hsieh M-L, Chiang J-H, Chang H-Y, Hsieh VC-R. Migraine and risk of narcolepsy in children: A nationwide longitudinal study. PLOS ONE. Public Library of Science; 2017;12:e0189231.

31. Suzuki K, Miyamoto T, Miyamoto M, et al. Dream-enacting behaviour is associated with impaired sleep and severe headache-related disability in migraine patients. Cephalalgia. 2013;33:868-878.

32. Kim SH, Park JY, Shin HE, et al. The influence of rapid eye movement sleep deprivation on nociceptive transmission and the duration of facial allodynia in rats: a behavioral and Fos immunohistochemical study. The Journal of Headache and Pain. 2019;20:21.

33. Lu J, Sherman D, Devor M, Saper CB. A putative flip-flop switch for control of REM sleep. Nature. 2006;441:589-594.

34. Feng H, Wen S-Y, Qiao Q-C, et al. Orexin signaling modulates synchronized excitation in the sublaterodorsal tegmental nucleus to stabilize REM sleep. Nature Communications. Nature Publishing Group; 2020;11:3661.

35. Palermo TM, Toliver-Sokol M, Fonareva I, Koh JL. Objective and Subjective Assessment of Sleep in Adolescents with Chronic Pain Compared to Healthy Adolescents. Clin J Pain. 2007;23:812-820.

36. Bruni O, Russo P, Violani C, Guidetti V. Sleep and Migraine: An Actigraphic Study. Cephalalgia. SAGE Publications Ltd STM; 2004;24:134-139.

37. Sivertsen B, Omvik S, Havik OE, et al. A Comparison of Actigraphy and Polysomnography in Older Adults Treated for Chronic Primary Insomnia. Sleep. 2006;29:1353-1358.

38. Borbély AA, Neuhaus HU. Sleep-deprivation: Effects on sleep and EEG in the rat. J Comp Physiol. 1979;133:71-87.

39. Rodríguez-Almagro D, Achalandabaso-Ochoa A, Obrero-Gaitán E, OsunaPérez MC, Ibáñez-Vera AJ, Lomas-Vega R. Sleep Alterations in Female College Students with Migraines. International Journal of Environmental 
medRxiv preprint doi: https://doi.org/10.1101/2021.03.03.21252791; this version posted March 5, 2021. The copyright holder for this preprint (which was not certified by peer review) is the author/funder, who has granted medRxiv a license to display the preprint in perpetuity.

583

584

585

586

587

588

589

590

591

592

593

594

595

596

597

598

599

600

601

602

603

604

605

606

607

608

609

610

611

612

613

614

615

616

617

618

619

620

621
Research and Public Health. Multidisciplinary Digital Publishing Institute; 2020;17:5456.

40. Sandoe $\mathrm{CH}$, Sasikumar S, Lay C, Lawler V. The Impact of Shift Work on Migraine: A Case Series and Narrative Review. Headache: The Journal of Head and Face Pain. 2019;59:1631-1640.

41. Slavin RE, Smith D. Effects of sample size on effect size in systematic reviews in education. Educational Evaluation and Policy Analysis. 2008;31:500-506.

42. Bjørk M, Sand T. Quantitative EEG Power and Asymmetry Increase $36 \mathrm{~h}$ Before a Migraine Attack. Cephalalgia. SAGE Publications Ltd STM; 2008;28:960-968.

43. Lorenzo J-L, Barbanoj M-J. Variability of sleep parameters across multiple laboratory sessions in healthy young subjects: The "very first night effect." Psychophysiology. 2002;39:409-413.

44. Grandner MA, Kripke DF, Yoon I-Y, Youngstedt SD. Criterion validity of the Pittsburgh Sleep Quality Index: Investigation in a non-clinical sample. Sleep Biol Rhythms. 2006;4:129-136.

45. Erwin AM, Bashore L. Subjective Sleep Measures in Children: Self-Report. Front Pediatr [online serial]. Frontiers; 2017;5. Accessed at: https://www.frontiersin.org/articles/10.3389/fped.2017.00022/full\#B8. Accessed January 10, 2021.

46. Collop NA. Scoring variability between polysomnography technologists in different sleep laboratories. Sleep Medicine. 2002;3:43-47.

47. Calhoun AH, Ford S. Behavioral Sleep Modification May Revert Transformed Migraine to Episodic Migraine. Headache: The Journal of Head and Face Pain. 2007;47:1178-1183.

48. Barbanti P, Fabbrini G, Aurilia C, Vanacore N, Cruccu G. A Case-Control Study on Excessive Daytime Sleepiness in Episodic Migraine. Cephalalgia. SAGE Publications Ltd STM; 2007;27:1115-1119.

49. Barbanti P, Aurilia C, Egeo G, Fofi L, Vanacore N. A case-control study on excessive daytime sleepiness in chronic migraine. Sleep Medicine. 2013;14:278-281.

50. Chu H-T, Liang C-S, Lee J-T, et al. Associations Between Depression/Anxiety and Headache Frequency in Migraineurs: A Cross-Sectional Study. Headache: The Journal of Head and Face Pain. 2018;58:407-415.

51. Engstrøm M, Hagen K, Bjørk MH, Stovner LJ, Sand T. Sleep quality and arousal in migraine and tension-type headache: the headache-sleep study. Acta Neurologica Scandinavica. 2014;129:47-54.

52. Gori S, Morelli N, Maestri M, Fabbrini M, Bonanni E, Murri L. Sleep quality, chronotypes and preferential timing of attacks in migraine without aura. $\mathrm{J}$ Headache Pain. BioMed Central; 2005;6:258-260. 
medRxiv preprint doi: https://doi.org/10.1101/2021.03.03.21252791; this version posted March 5, 2021. The copyright holder for this preprint (which was not certified by peer review) is the author/funder, who has granted medRxiv a license to display the preprint in perpetuity.

622

623

624

625

626

627

628

629

630

631

632

633

634

635

636

637

638

639

640

641

642

643

644

645

646

647

648

649

650

651

652

653
53. Karthik N, Kulkarni GB, Taly AB, Rao S, Sinha S. Sleep disturbances in 'migraine without aura' - A questionnaire based study. Journal of the Neurological Sciences. 2012;321:73-76.

54. Kozak HH, Boysan M, Uca AU, et al. Sleep quality, morningness-eveningness preference, mood profile, and levels of serum melatonin in migraine patients: a case-control study. Acta neurologica Belgica. Springer; 2017;117:111-119.

55. Lin Y-K, Liang C-S, Lee J-T, et al. Association of Suicide Risk With Headache Frequency Among Migraine Patients With and Without Aura. Front Neurol [online serial]. Frontiers; 2019;10. Accessed at: https://www.frontiersin.org/articles/10.3389/fneur.2019.00228/full. Accessed November 26, 2020.

56. Morgan I, Eguia F, Gelaye B, et al. Sleep disturbances and quality of life in SubSaharan African migraineurs. The Journal of Headache and Pain. 2015;16:18.

57. Rafique N, Al-Asoom LI, Latif R, et al. Prevalence of Migraine and its Relationship with Psychological Stress and Sleep Quality in Female University Students in Saudi Arabia. J Pain Res. 2020;13:2423-2430.

58. Rockett FC, Perla A da S, Perry IDS, Chaves MLF. Cardiovascular disease risk in women with migraine. The Journal of Headache and Pain. 2013;14:75.

59. Song T-J, Yun C-H, Cho S-J, Kim W-J, Yang KI, Chu MK. Short sleep duration and poor sleep quality among migraineurs: A population-based study. Cephalalgia. SAGE Publications Ltd STM; 2018;38:855-864.

60. van Oosterhout W, van Someren E, Schoonman G, et al. Chronotypes and circadian timing in migraine. Cephalalgia. SAGE Publications Ltd STM; 2018;38:617-625.

61. Walters AB, Hamer JD, Smitherman TA. Sleep Disturbance and Affective Comorbidity Among Episodic Migraineurs. Headache: The Journal of Head and Face Pain. 2014;54:116-124. 
medRxiv preprint doi: https://doi.org/10.1101/2021.03.03.21252791; this version posted March 5, 2021. The copyright holder for this preprint (which was not certified by peer review) is the author/funder, who has granted medRxiv a license to display the preprint in perpetuity. All rights reserved. No reuse allowed without permission.

\section{7. Tables}

\section{Table 1: Methodological characteristics of the studies include in the meta-analysis}

\begin{tabular}{|c|c|c|c|c|c|c|c|c|}
\hline $\begin{array}{l}\text { First author } \\
\text { (year) }\end{array}$ & $\begin{array}{l}n \text { total } \\
(\mathrm{Mi}, \mathrm{C})\end{array}$ & $\begin{array}{c}\text { Age: mean } \\
\quad \pm \text { SD } \\
\text { (Mi, C) }\end{array}$ & $\begin{array}{l}\text { Sex ratio } \\
\text { (M:F) (Mi, } \\
\text { C) }\end{array}$ & $\begin{array}{l}\text { Migraine } \\
\text { frequency }\end{array}$ & $\begin{array}{c}\text { Migraine } \\
\text { classificatio } \\
\text { n }\end{array}$ & $\begin{array}{l}\text { Control } \\
\text { population }\end{array}$ & $\begin{array}{l}\text { Sleep } \\
\text { outcomes }\end{array}$ & $\begin{array}{l}\text { Medication } \\
\text { exclusion? }\end{array}$ \\
\hline $\begin{array}{l}\text { Armoni } \\
\text { Domany et al. } \\
(2019)^{25}\end{array}$ & $365(185,180)$ & $\begin{array}{c}13.5 \pm 3.4,9.7 \\
\pm 2\end{array}$ & $72: 113,88: 92$ & episodic & $\mathrm{MO} \& \mathrm{MA}$ & $\begin{array}{c}\text { Non-matched } \\
\text { controls }\end{array}$ & PSG & No \\
\hline $\begin{array}{l}\text { Barbanti et al. } \\
(2007)^{48}\end{array}$ & $200(100,100)$ & $\begin{array}{l}36.9 \pm 12.1 \\
36.7 \pm 11.7\end{array}$ & $16: 84$ (total) & episodic & $\mathrm{MO}$ and MA & $\begin{array}{l}\text { Age and sex } \\
\text { matched } \\
\text { controls }\end{array}$ & PSQI & Yes \\
\hline $\begin{array}{l}\text { Barbanti et al. } \\
(2013)^{49}\end{array}$ & $200(100,100)$ & $\begin{array}{c}46.8 \pm 13.8 \\
(\mathrm{M})\end{array}$ & $8: 92$ (total) & chronic & $\mathrm{MO}$ and $\mathrm{MA}$ & $\begin{array}{l}\text { Age and sex } \\
\text { matched } \\
\text { controls }\end{array}$ & PSQI & Yes \\
\hline $\begin{array}{l}\text { Chu et al. } \\
(2018)^{50}\end{array}$ & $244(65,179)$ & $\begin{array}{l}32.0 \pm 12.6 \\
34.7 \pm 11.9\end{array}$ & $20: 45,63: 116$ & $\begin{array}{c}\text { episodic and } \\
\text { chronic }\end{array}$ & $\mathrm{MO}$ and $\mathrm{MA}$ & $\begin{array}{c}\text { Non-matched } \\
\text { controls }\end{array}$ & PSQI & Unknown \\
\hline $\begin{array}{l}\text { Della Marca et } \\
\text { al. }(2006)^{15}\end{array}$ & $20(10,10)$ & $\begin{array}{l}41.9 \pm 13.9 \\
43.2 \pm 16.9\end{array}$ & $3: 7,3: 7$ & episodic & $\mathrm{MO}$ & $\begin{array}{l}\text { Age and sex } \\
\text { matched } \\
\text { controls }\end{array}$ & PSG & $\begin{array}{c}\text { Yes - except } \\
\text { triptans and } \\
\text { NSAIDs }\end{array}$ \\
\hline $\begin{array}{l}\text { Dikmen et al., } \\
(2015)^{12}\end{array}$ & $128(87,41)$ & - & $25: 62,16: 25$ & episodic & $\mathrm{MO}$ and $\mathrm{MA}$ & $\begin{array}{c}\text { Non-matched } \\
\text { controls }\end{array}$ & PSQI & Yes \\
\hline $\begin{array}{l}\text { El-Heenedy et } \\
\text { al. }(2019)^{22}\end{array}$ & $60(40,20)$ & $\begin{array}{c}11.13 \pm 2.85 \\
(\mathrm{Mi}),-\end{array}$ & 17:23 (Mi), - & $\begin{array}{c}\text { episodic and } \\
\text { chronic }\end{array}$ & $\mathrm{MO}$ and $\mathrm{MA}$ & $\begin{array}{l}\text { Age and sex } \\
\text { matched } \\
\text { controls }\end{array}$ & PSG, PSQI, & Yes \\
\hline $\begin{array}{l}\text { Engstrom et } \\
\text { al., }(2013)^{16}\end{array}$ & $\begin{array}{c}34(\mathrm{C}), 15 \\
(\mathrm{SRM}), 18 \\
\text { (NSRM) }\end{array}$ & $\begin{array}{l}33.9 \pm 11.4 \\
39.4 \pm 14.3\end{array}$ & $\begin{array}{c}\text { 5:10 (SRM), } \\
3: 15 \text { (NSRM), } \\
14: 20(\mathrm{C})\end{array}$ & episodic & $\begin{array}{c}\text { MO and MA, } \\
\text { SRM and } \\
\text { NSRM }\end{array}$ & $\begin{array}{l}\text { Age and sex } \\
\text { matched } \\
\text { controls }\end{array}$ & PSG, PSQI, & $\begin{array}{c}\text { Yes - except } \\
\text { triptans and } \\
\text { NSAIDs }\end{array}$ \\
\hline $\begin{array}{l}\text { Engstrom et } \\
\text { al., }(2014)^{51}\end{array}$ & $87(53,34)$ & $\begin{array}{c}38.2 \pm 12 \\
39.6 \pm 13.7\end{array}$ & $12: 41,14: 20$ & episodic & $\mathrm{MO}$ and MA & $\begin{array}{l}\text { Age and sex } \\
\text { matched } \\
\text { controls }\end{array}$ & PSG, PSQI, & $\begin{array}{c}\text { Yes - except } \\
\text { triptans and } \\
\text { NSAIDs }\end{array}$ \\
\hline $\begin{array}{l}\text { Esposito et al. } \\
(2013)^{23}\end{array}$ & $85(34,51)$ & $\begin{array}{l}9.08 \pm 2.28 \\
9.37 \pm 1.81\end{array}$ & $20: 14,28: 23$ & episodic & $\mathrm{MO}$ & $\begin{array}{l}\text { Age and sex } \\
\text { matched } \\
\text { controls }\end{array}$ & PSG & $\begin{array}{c}\text { Yes - } \\
\text { psychoactive } \\
\text { drugs }\end{array}$ \\
\hline $\begin{array}{l}\text { Gori et al., } \\
(2005)^{52}\end{array}$ & $\begin{array}{c}200 \text { (78 SRM, } \\
122 \text { NSRM) }\end{array}$ & $\begin{array}{c}40.1 \pm 11.2 \\
(\text { total })\end{array}$ & $22: 178$ (total) & episodic & $\mathrm{MO}$ and MA & - & PSQI & Unknown \\
\hline $\begin{array}{l}\text { Karthik et al., } \\
(2012)^{53}\end{array}$ & $180(90,90)$ & $\begin{array}{l}31.76 \pm 8.2 \\
31.76 \pm 8.2\end{array}$ & $19: 71,19: 71$ & episodic & $\mathrm{MO}$ & $\begin{array}{l}\text { Age and sex } \\
\text { matched } \\
\text { controls }\end{array}$ & PSQI & Yes \\
\hline
\end{tabular}


medRxiv preprint doi: https://doi.org/10.1101/2021.03.03.21252791; this version posted March 5, 2021. The copyright holder for this preprint (which was not certified by peer review) is the author/funder, who has granted medRxiv a license to display the preprint in perpetuity.

All rights reserved. No reuse allowed without permission.

31

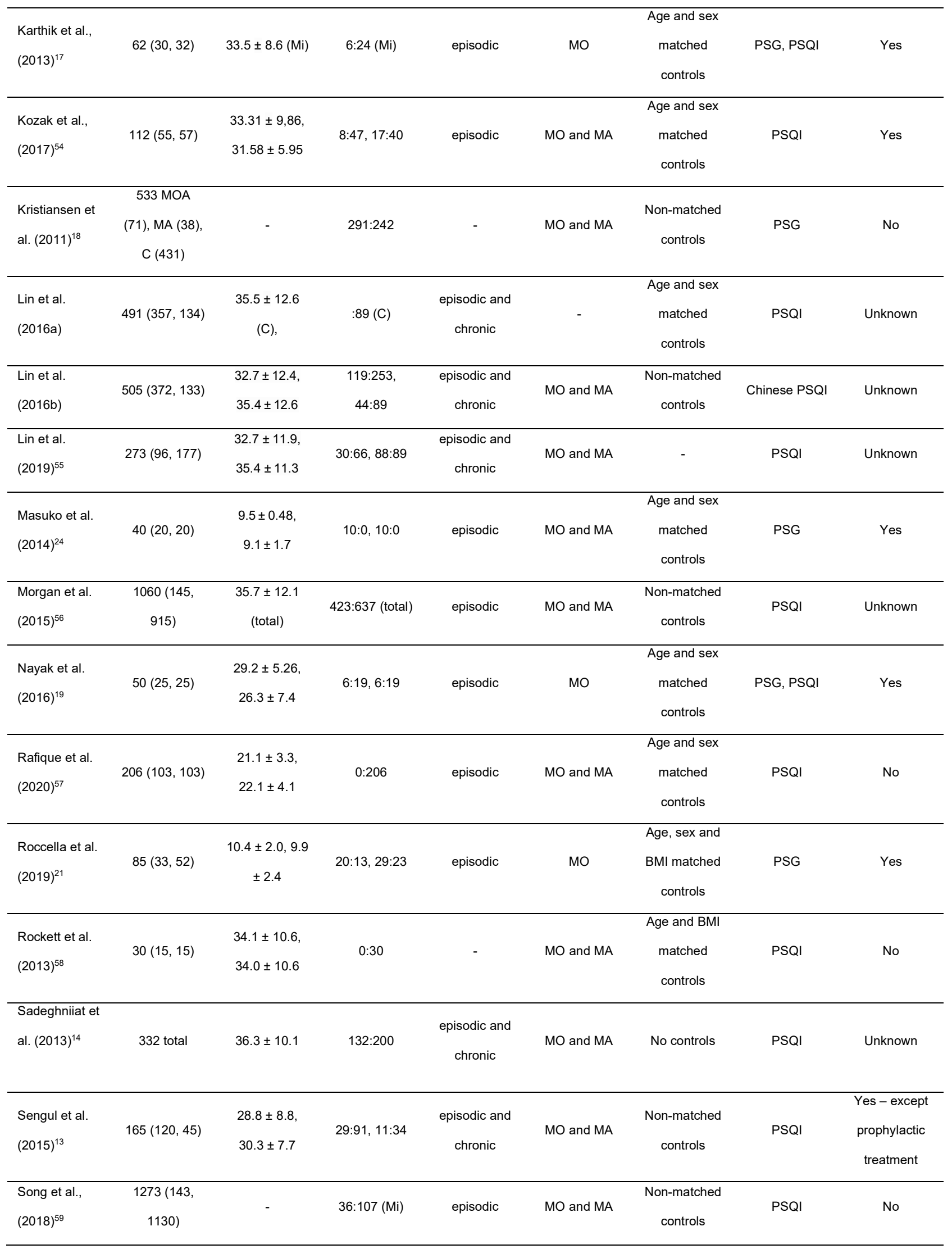


medRxiv preprint doi: https://doi.org/10.1101/2021.03.03.21252791; this version posted March 5, 2021. The copyright holder for this preprint (which was not certified by peer review) is the author/funder, who has granted medRxiv a license to display the preprint in perpetuity.

All rights reserved. No reuse allowed without permission.

32

\begin{tabular}{|c|c|c|c|c|c|c|c|c|}
\hline $\begin{array}{l}\text { Suzuki et al. } \\
(2013)^{31}\end{array}$ & $301(161,140)$ & $\begin{array}{c}33.1 \pm 10.0 \\
33.1 \pm 6.4\end{array}$ & $\begin{array}{l}35: 126 \\
14: 126\end{array}$ & episodic & $\mathrm{MO}$ and $\mathrm{MA}$ & $\begin{array}{c}\text { Non-matched } \\
\text { controls }\end{array}$ & PSQI & Unknown \\
\hline \multicolumn{9}{|l|}{ Van } \\
\hline $\begin{array}{l}\text { Oosterhout et } \\
\text { al. }(2018)^{60}\end{array}$ & $\begin{array}{c}2578(2389 \\
189)\end{array}$ & $\begin{array}{l}45.1 \pm 11.7 \\
46.4 \pm 14.2\end{array}$ & $\begin{array}{c}351: 2047, \\
87: 102\end{array}$ & episodic & $\mathrm{MO}$ and $\mathrm{MA}$ & $\begin{array}{c}\text { Non-matched } \\
\text { controls }\end{array}$ & PSQI & Unknown \\
\hline $\begin{array}{l}\text { Vollono et al. } \\
(2013)^{20}\end{array}$ & $16(8,8)$ & $\begin{array}{c}48.1 \pm 9.3 \\
46.7 \pm 10.7\end{array}$ & $2: 6,2: 6$ & - & SRM & $\begin{array}{l}\text { Age and sex } \\
\text { matched } \\
\text { controls }\end{array}$ & PSG & $\begin{array}{l}\text { Yes - except } \\
\text { triptans and } \\
\text { NSAIDs }\end{array}$ \\
\hline $\begin{array}{l}\text { Walters et al. } \\
(2014)^{61}\end{array}$ & $286(78,208)$ & $\begin{array}{c}19.2 \pm 3.1 \\
\text { (total) }\end{array}$ & $20: 58,68: 140$ & episodic & $\mathrm{MO}$ and $\mathrm{MA}$ & $\begin{array}{c}\text { Non-matched } \\
\text { controls }\end{array}$ & PSQI & Unknown \\
\hline $\begin{array}{l}\text { Yon et al. } \\
(2020)^{11}\end{array}$ & $42(21,21)$ & $\begin{array}{l}33.5 \pm 10.1 \\
32.8 \pm 7.23\end{array}$ & - & chronic & $\mathrm{MO}$ and MA & $\begin{array}{l}\text { Age and sex } \\
\text { matched } \\
\text { controls }\end{array}$ & PSQI & Yes \\
\hline
\end{tabular}

658 polysomnography, MIDAS = Migraine Disability Assessment, BMI = Body Mass Index, MO = migraine without aura, MA = migraine with aura, SRM = sleep-

659 related migraine, NSRM = non-sleep-related migraine, NSAIDs = Nonsteroidal anti-inflammatory drugs. 
Table 2: Results of the meta-analysis of PSG-derived sleep variables in adult migraineurs and control participants

\begin{tabular}{|c|c|c|c|c|c|c|c|c|}
\hline Parameter & $N$ studies & $\begin{array}{c}N \text { participants } \\
(\mathrm{C}, \mathrm{Mi})\end{array}$ & Hedges' $g$ & $p$ & $\boldsymbol{Q}$ & $I^{2}(\%)$ & References & $\mathrm{C}>\mathrm{Mi}, \mathrm{Mi}>\mathrm{C}$ \\
\hline $\begin{array}{l}\text { Total Sleep } \\
\text { Time (mins) }\end{array}$ & 6 & 532,169 & 0.10 & 0.282 & 1.95 & 1.95 & $15,17-20,51$ & \\
\hline $\begin{array}{l}\text { Sleep Onset } \\
\text { Latency } \\
\text { (mins) }\end{array}$ & 5 & 515,152 & 0.24 & 0.100 & 5.49 & 32.56 & $15,17,18,20,51$ & \\
\hline $\begin{array}{l}\text { Sleep } \\
\text { Efficiency (\%) }\end{array}$ & 4 & 505,142 & -0.08 & 0.728 & 10.0 & 73.25 & $17,18,20,51$ & \\
\hline Wake (\%) & 3 & 65,63 & 0.58 & 0.053 & 4.48 & 57.89 & $17,19,20$ & \\
\hline N1 (\%) & 6 & 540,177 & 0.10 & 0.515 & 10.03 & 44.16 & $15,17-20,51$ & \\
\hline N2 (\%) & 6 & 540,177 & 0.11 & 0.458 & 8.33 & 43.10 & $15,17-20,51$ & \\
\hline N3 (\%) & 6 & 540,177 & -0.24 & 0.091 & $8.25^{*}$ & 42.99 & $15,17-20,51$ & \\
\hline REM (\%) & 6 & 540,177 & $-0.22^{*}$ & 0.017 & 2.27 & 0.00 & $15,17-20,51$ & \\
\hline
\end{tabular}

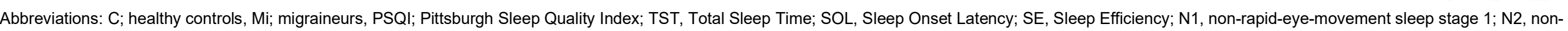
rapid-eye-movement sleep stage 2; N3, non-REM sleep stage 3 
Table 3: Results of the meta-analysis of PSG-derived sleep variables in pediatric migraineurs and control participants

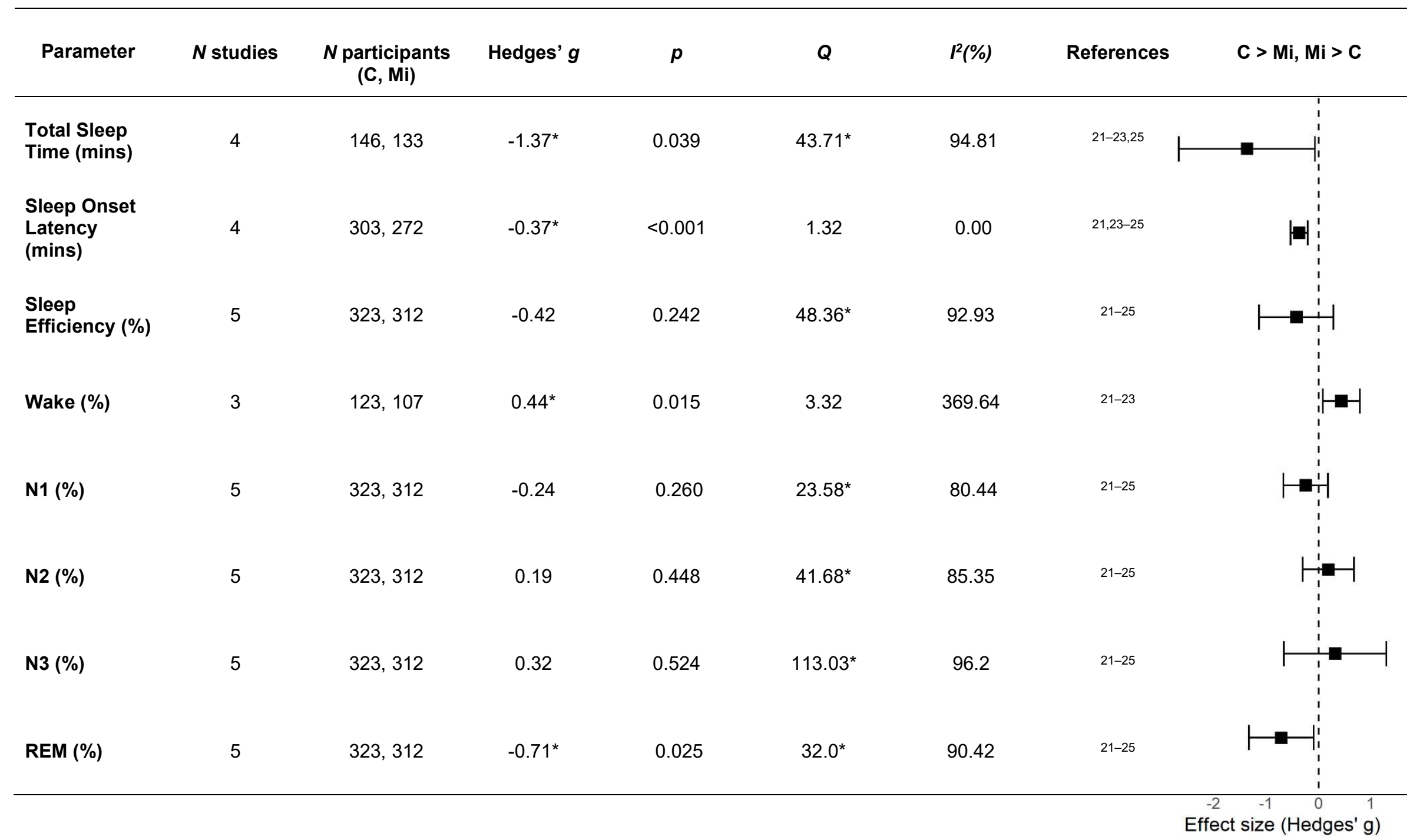

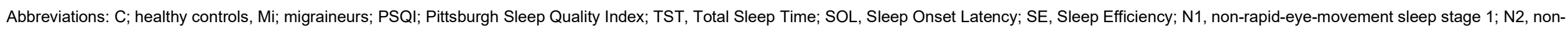
rapid-eye-movement sleep stage 2; N3, non-REM sleep stage 3 
medRxiv preprint doi: https://doi.org/10.1101/2021.03.03.21252791; this version posted March 5, 2021. The copyright holder for this preprint (which was not certified by peer review) is the author/funder, who has granted medRxiv a license to display the preprint in perpetuity. All rights reserved. No reuse allowed without permission.

Table 4: Results of the moderator analysis of global PSQI scores in adult migraineurs

\begin{tabular}{llclll}
\hline Analysis & $\boldsymbol{Q}_{M}$ & $\boldsymbol{P}$ & $\boldsymbol{\beta}$ & $\boldsymbol{Q}_{E}$ & $\boldsymbol{p}$ \\
\hline Sleep disorders excluded & $7.40^{*}$ & 0.007 & -0.81 & $114.61^{*}$ & $<.001$ \\
\hline Matched controls & 0.02 & 0.878 & 0.03 & $161.41^{*}$ & $<.001$ \\
\hline Medications excluded & 0.32 & 0.572 & 0.13 & $160.34^{*}$ & $<.001$ \\
\hline
\end{tabular}

Abbreviations: PSQI = Pittsburgh Sleep Quality Index

Table 5: Results of the moderator analysis of PSG-derived sleep variables in pediatric migraineurs

\begin{tabular}{lccccc}
\hline Analysis & $Q_{M}$ & $\boldsymbol{p}$ & $\boldsymbol{\beta}$ & $\boldsymbol{Q}_{E}$ & $\boldsymbol{p}$ \\
\hline Adaptation night & & & & & \\
\hline TST & 0.20 & 0.655 & -0.69 & $38.46^{*}$ & $<.001$ \\
REM & 0.01 & 0.931 & 0.10 & $28.37^{*}$ & $<.001$ \\
\hline Matched controls & & & & \\
\hline TST & $19.60^{*}$ & $<.001$ & -2.51 & 4.75 & 0.093 \\
REM & 0.80 & 0.372 & -0.70 & $17.73^{*}$ & $<.001$ \\
\hline Medications excluded & & & & \\
\hline TST & $19.60^{*}$ & $<.001$ & -2.51 & 4.75 & 0.093 \\
REM & 0.80 & 0.372 & -0.70 & $17.73^{*}$ & $<.001$ \\
\hline
\end{tabular}

Abbreviations: TST = total sleep time, REM = rapid-eye-movement sleep, $\mathrm{PSG}=$ polysomnography 